\title{
RESPONSE
}

\section{Jewish Theology and Limits on Reciprocity in Catholic-Jewish Dialogue}

\author{
Adam Gregerman, Institute for Christian \& Jewish Studies
}

A Response to Cardinal Kurt Koch's October 30, 2011 Keynote Address at Seton Hall University during the $10^{\text {th }}$ Annual Meeting of the Council of Centers on Christian-Jewish Relations

The Catholic Church, more than any other Christian group or institution, has made a dramatic break with centuries of anti-Judaism. It has persisted in revising its teachings despite enormously complex and fraught theological issues about God, Christ, and salvation. Cardinal Kurt Koch's speech at Seton Hall University on October 30, 2011 continued this trajectory. He was theologically sophisticated, gracious, and also controversial. His speech, with its mix of unproblematic and also provocative claims, illustrates the difficult process by which Catholics rethink their views about Jews and Judaism. Importantly, he nobly commits himself and the Church to improved interreligious relations, and his speech makes a valuable contribution to theological reflection on issues related to the ongoing legitimacy of the Jewish covenant with God. However, he also presents some claims about Judaism that are questionable and makes some requests of Jews that will be met with reluctance and even judged unacceptable.

In my response to his speech, I will first situate his statements in the context of earlier Catholic statements about Jews and Judaism. I will highlight examples of both continuity and discontinuity and offer possible explanations for some of the distinctive claims he makes. I will then consider in more depth selected passages that contain important but controversial statements. These passages, I will argue, employ a reciprocal, dialogical format, and express requests to Jews for some type of change in belief in response to Catholic theological changes. These, I believe, are likely to meet with Jewish resistance. However, I intend for my comments to be read not just as dissents but as opportunities for continuing reflection and learning.

\section{Koch and Earlier Catholic Statements on Jews and Judaism}

Many of the claims in Koch's speech resemble those found in seminal Catholic texts from the previous few decades. He often refers to or echoes Vatican documents, such as Nostra Aetate ${ }^{1}$ (1965) and Notes on the Correct Way to Present the Jews and Judaism in Preaching and Catechesis in the Roman Catholic Church ${ }^{2}$ (1985), and statements by the two most recent popes. The latter category is well-represented, in light of John Paul II's and Benedict XVI's interest in these subjects and relatively frequent references to them in speeches and writings. Not surprisingly, Koch, as a representative of the Church, emphasizes continuity with these earlier views. The touchstone of all post-Shoah Catholic reflection is the path-breaking Nostra Aetate.

\footnotetext{
${ }^{1}$ http://www.vatican.va/archive/hist_councils/ii_vatican_council/documents/vat-ii_decl_19651028_nostraaetate_en.html.

${ }^{2}$ http://www.vatican.va/roman_curia/pontifical_councils/chrstuni/relations-jewsdocs/rc_pc_chrstuni_doc_19820306_jews-judaism_en.html.
} 
As a sign of a subtle evolution in recent Catholic views of Jews, the rejection of the accusation that the Jews eternally bear responsibility for the Crucifixion was an especially notable (and controversial) claim at Vatican II in the 1960s. However, it was only after some time that the brief remarks in Nostra Aetate about God's continuing covenant with the Jews, not the rejection of the deicide charge, took center stage. That trend is evident here as well.

As a Jew, I am of course pleased with the shift. While the deicide charge was scurrilous and often dangerous, topics such as covenant, election, and salvation are appropriate for serious and constructive reflection. For obvious reasons, they are also far more conducive to dialogue with Jews. Koch largely focuses on these topics, all of them premised on the Church's affirmation of the Jewish covenant with God. I recognize with genuine sympathy the complexity of this inquiry. Acceptance of the legitimacy of Judaism has profound implications for Catholic faith. In the words of Mary Boys, "Once one pulls out the thread of supersessionism, it becomes necessary to reweave the entire cloth." ${ }^{3}$ While Koch might not express the challenge so radically, in the first three sentences alone he notes three times (and many times afterward) just how "complex" his task is. Likewise, he situates his response to the challenge in Catholics' experiences of living in "multi-religious" societies. Rather than minimize the influence of "daily contact" between Catholics and others, he recognizes that an encounter with diversity can be a healthy spur to new theological thinking. ${ }^{4}$

Prior to the theological reflections that comprise the bulk of the speech, Koch wades into some contentious historical issues. He reiterates past Catholic statements that originally provoked disagreement, especially regarding the Shoah, but, importantly, adds sometimes oblique observations that seem to explain or mitigate them. (To his credit, in no case does he appear to ratchet up the controversy.) This mixed response is evident in a comparison of his statement with the highly controversial Vatican document We Remember: A Reflection on the Shoah ${ }^{5}$ (1998). On the one hand, Koch reinforces some of the divisive claims in We Remember. Just as in the document, he categorically denies any connection between Christian anti-Judaism and Nazi antisemitism. The roots of the latter lie in anti-Christian paganism that has "nothing in common with Christianity." Stylistically, he employs some of the same awkward negative phraseology found in We Remember. Christians "did not display that vigour and clarity which one should by rights have expected," and "not a few Christians" held anti-Jewish views.

On the other hand, he subtly and constructively alters some earlier ideas. He says nothing about Christian aid to persecuted Jews, perhaps recognizing that the claim in We Remember that "many" gave "every possible assistance to those being persecuted" was an overstatement. Also, the 1998 text distanced the Church and its leaders from Nazi atrocities. For example, the guilty were "sons and daughters of the Church," never clergy or anti-Jewish preachers. Koch speaks

\footnotetext{
${ }^{3}$ Mary C. Boys, "The Nostra Aetate Trajectory: Holding Our Theological Bow Differently," in Never Revoked: Nostra Aetate as Ongoing Challenge for Jewish-Christian Dialogue, ed. Marianne Moyaert and Didier Pollefeyt (Grand Rapids, MI: Eerdmans, 2010): 133-57, 133-34.

${ }^{4}$ This view was recently expressed by two Catholic theologians: "Interreligious dialogue is therefore an important touchstone for every theological enterprise that considers religious others," in Philip A. Cunningham and Didier A. Pollefeyt, "The Triune One, the Incarnate Logos, and Israel's Covenantal Life," in Christ Jesus and the Jewish People Today: New Explorations of Theological Interrelationships, ed. Philip A. Cunningham, et al. (Grand Rapids, Ml: William B. Eerdmans, 2011): 183-201, 193-94.

5

http://www.vatican.va/roman_curia/pontifical_councils/chrstuni/documents/rc_pc_chrstuni_doc_16031998_shoah_en. html. On the controversy over We Remember, see Kevin Madigan, "A Survey of Jewish Reaction to the Vatican Statement on the Holocaust," in Remembering for the Future: The Holocaust in an Age of Genocides, ed. John K. Roth and Elisabeth Maxwell (New York: Palgrave, 2001): 425-36.
} 
more inclusively about the failure of "us Christians" to stop Nazi atrocities. Implicitly, he critiques the tendency to leave hard questions unanswered. We Remember asked but did not answer the question, "Did anti-Jewish sentiment among Christians" make them indifferent to Jewish suffering? Koch is more forthright: "anti-Judaism had been in effect for centuries, fostering a widespread anti-Semitic apathy against the Jews" that abetted Nazism. What was originally tentative is now declarative. Admittedly, it is difficult to ascertain just how significant some of these sentences and phrases are; Koch never openly signals any disagreement. However, the clear echoes of the earlier text suggest thoroughgoing familiarity with it and the likelihood that he is involved in an ongoing refinement of the Church's views.

Similarly, Koch engages with Benedict's speech at Auschwitz in 2006, sometimes affirming his claims, other times subtly modifying them or responding to negative reactions to them. ${ }^{6}$ Among the pope's most controversial statements was that Nazi hostility to the Jews reflected a "desire to tear up the taproot of Christian faith." This statement, some critics said, placed Christians on the side of the murdered Jews and cast members of both religions as actual or potential victims of an irreligious ideology. ${ }^{7}$ Koch does not entirely disagree. He reinforces Benedict's broader argument, attacking secularism and a "heathen world view" that disdained theistic faith. He too thinks fault for these events lies with modern racist trends above all, which led to Nazi anti-Jewish violence and would have led to widespread "anti-Christian" violence as well. However, he indicates his awareness that the speech was criticized for presenting Christians as (potential) victims. Referring to such criticism, he denies that Benedict's statement was intended to be "an evasion of the guilty complicity of Christians."

Rather, Koch takes the idea of shared vulnerability in Benedict's speech in a different direction than Benedict. Benedict included a highly provocative reference to Edith Stein, a Jewish convert to Catholicism murdered as a Jew in Auschwitz. (She is the only Jew he mentioned by name.) Many Jews and Catholics were critical of the Church's designation of her as a martyr, for she was murdered as a Jew. ${ }^{8}$ Benedict, however, rekindling memories of the dispute over Stein as he spoke at this location, effaced the differences between the two religions and the different consequences for members of each under Nazism, calling her both "a Christian and a Jew."

Koch not only omits any mention of Stein but draws on Benedict's speech to develop a different argument about the "shared patrimony" of the two faiths. He does not efface their distinctiveness, but affirms both a deep connection between them along with historical and theological separation. He stresses a theological unity, manifest in fidelity to shared Scriptures and to the God of Israel by Jews and Christians alike. He also grants the "divergence" between them, which contributed to mistrust and often hostility. This important argument, glimpsed in his discussion of Auschwitz, reappears in various forms throughout the entire statement, though here it hints at a possible shift away from some of less palatable parts of Benedict's speech. More importantly, he signals his interest in exploring the nature of the connection between these two religious traditions. And it is this theme that will occupy Koch for most of the remainder of his statement.

\footnotetext{
${ }^{6}$ http://www.vatican.va/holy_father/benedict_xvi/speeches/2006/may/documents/hf_benxvi_spe_20060528_auschwitz-birkenau_en.h.html.

7 See John L. Allen, Jr., "Attempting to Slay God was Auschwitz's Greatest Evil, Pope Says," National Catholic Reporter, May 28, 2006; Peter Manseau, "Catholics \& the Shoah: Appropriating the Suffering of Others," Commonweal, March 13, 2009. Similar claims to Benedict's at Auschwitz were expressed earlier in We Remember: $A$ Reflection on the Shoah.

${ }^{8}$ A Vatican statement on Stein can be found at http://www.vatican.va/news_services/liturgy/saints/ns_lit_doc_19981011_edith_stein_en.html.
} 
Koch's Reflections on Judaism and Requests to Jews

I next want to focus closely on three passages that reveal Koch's sophisticated reflections on "the elementary tension in the relationship of the two faith communities." These passages, which already have prompted lively discussions among Jews and Catholics, are some of the most provocative and controversial in his speech. I have chosen them because they raise issues with great contemporary relevance to Jewish-Catholic relations generally. Unlike the more numerous, less controversial passages, these impel us to grapple with unsettled and difficult issues. Also, I have chosen them because they reveal a shift in the form of the reflections by Church leaders. Not only does Koch report on the results of internal Church discussions about Jews to Jews and others in these passages (as commonly happens in such statements), but he introduces a dialogical format that includes requests for a specific response from Jews. However, I will argue that such theological reciprocity to Koch's requests is probably impossible because he makes some unacceptable demands of Jews. Also, the dialogical format is undermined by his posing questions that seem to emerge entirely from Catholic theological concerns rather than from discussions with Jews about issues important to both communities. Nonetheless, the requests he makes in these passages offer fruitful opportunities for continuing Jewish-Catholic discussions. Therefore, my critical evaluations should not obscure my deep appreciation for his contribution, and above all for his insistence on mutual respect and even love. This is surely a reciprocal obligation.

\section{Quotation 1:}

"...Jews could with regard to the Abrahamic covenant arrive at the insight that Israel without the church would be in danger of remaining too particularist. In this fundamental sense Israel and the church remain bound up with one another according to the covenant and interdependent on one another" (Part 2b).

A prominent topic in Koch's statement, and in recent Catholic statements about Jews and Judaism, is the Abrahamic covenant. ${ }^{9}$ Koch affirms the centrality and eternality of the Abrahamic covenant in Jewish religious identity. Such a covenant could not be broken, for God is faithful. Koch also emphasizes the universal aspects of God's promises to Abraham and the patriarchs in order to ground Christian faith, which extends beyond the bounds of Israel to "all peoples," in this foundational and shared biblical covenant. Importantly, and not surprisingly, he argues that this expansion of faith to all was not accidental but "originally intended" by God when the Abrahamic covenant was made. That is, the offer of faith in the God of Israel to Gentiles through Christ is an inherent part of the Abrahamic covenant from its inception. Though he does not quote relevant verses in Genesis (e.g., 12:3; 17:4-5; 28:14), he surely has in mind biblical references to the blessings of the nations and families of the world included in God's promises to Abraham and his descendants. ${ }^{10}$

Christian allusions to and citations of biblical passages that demonstrate divine solicitude for the nations are ubiquitous from the first century through the present. Many refer to the promises to Abraham to legitimate the emergence of a church not restricted by the boundaries of the people

9 E.g., The Jewish People and their Sacred Scriptures in the Christian Bible 28, 37; at http://www.vatican.va/roman_curia/congregations/cfaith/pcb_documents/rc_con_cfaith_doc_20020212_popoloebraico_en.html.

${ }^{10}$ E.g., Jewish People 54. 
of Israel. ${ }^{11}$ Until the Shoah, most Christians read such texts as if God's covenantal promises to the Jews were canceled and transferred to believing Christians. However, in the post-Vatican II Church, such passages are no longer read as applying exclusively either to Christians or to Jews.

Koch exemplifies this recent and welcome trend, breaking with an older, zero-sum view of covenantal blessings. Abraham "is not only the father of Israel but also the father of the faith of Christians," he writes. The present tense ("is...the father") is significant, making clear that his claim applies not only to Jews in the pre-Christian period but to Jews who lived and live after Jesus, up through the present. ${ }^{12}$ Even those Jews who refused and refuse to believe that Jesus was the promised Messiah remain in this covenant.

This argument, while breaking little new ground theologically, continues a salutary trend in Catholic teachings about Jews and Judaism. I heartily welcome this affirmation. It fits with longstanding Jewish theological claims about the enduring status of the covenant with Abraham. It is especially important after a long and hostile Christian supersessionist tradition. While there is more that could be said about his interpretation of the Abrahamic theme, I want to focus on his conclusion (quoted above), for here he introduces a distinctive idea. In essence he asks: Since the Church affirms that God covenanted and covenants with the Jewish people, might Jews affirm a divine intention to spread faith in the God of Israel to the nations and bring them into the Abrahamic covenant through Christianity? Before considering the form of this claim-an implicit request to Jews to "arrive at the insight" he offers-I want to explore the content of the argument he makes about this expansion of covenantal membership and the ways it rests upon a contrast between Jewish particularism and Christian universalism.

Koch alludes to traditional tropes about a lack or insufficiency in Judaism that Christianity remedies and about divine intentions that Christianity fulfills. Specifically, he posits a "particularistic" Judaism that limits the expansion of the Abrahamic promises to non-Jews. Without Christianity, the original goal of the promises would be dashed. Christianity is therefore a corrective to Jewish exclusivism, bringing what God intended to its fruition.

Koch is undeniably correct to note restrictive elements in Jewish interpretation of the covenant. Jews traditionally defined the boundaries of their religious community in terms of descent from Abraham. There are limits on religious membership, though these are not impermeable or biological; converts are acceptable. Faith in the God of Israel or the performance of moral actions, for example, do not alone suffice to bring a Gentile into the covenant with Abraham. With a very few possible exceptions, Jews did not and do not missionize. The implications of these views, however, are not explored by Koch, which obfuscates his claim that Jewish particularism poses some type of (theological) "danger."

On the contrary, I believe Jewish views of the covenant with Abraham could just as easily be described as exceedingly welcoming to Gentiles. Traditionally, those outside the Jewish community are not thereby cut off from God. For example, many Jewish texts do not reflect a dualistic division of humanity into the saved (meaning Jews in the covenant) and the damned (meaning

\footnotetext{
${ }^{11}$ On the place of Abraham in these promises, see Jeffrey S. Siker, Disinheriting the Jews: Abraham in Early Christian Controversy (Louisville, KY: Westminster / John Knox, 1991).

12 This follows similar statements in Notes on the Correct Way 33. Despite this statement, however, it should be noted that Koch gives very little attention to post-Jesus Judaism.
} 
Gentiles outside the covenant), with the latter categorically deserving of divine punishment. ${ }^{13}$ Jews, without having reason to worry about the dreadful fate that awaits Gentiles, lack any motivation to bring Gentiles into the covenant community. This undermines the idea that Jewish particularism regarding the covenant with Abraham poses some unspecified kind of "danger."14 Rather, a prominent idea in Jewish thought, already in biblical and rabbinic texts, sees "particularism" (perhaps better, chosenness or election) without any negative implications for the unchosen. From a Jewish perspective, there is no harm to Gentiles in a restrictive understanding of the Abrahamic covenant; perhaps the blessings to the nations could be mediated in other ways. ${ }^{15}$

Koch, however, uses a specifically Christian standard to evaluate the Abrahamic covenant in Judaism: Does the covenant allow for the full inclusion of Gentiles into the contemporary religious community? It is this standard he uses to judge the boundaries a religious community sets up between insiders and outsiders. By this explicitly Christian standard, Judaism is judged wanting, for it does not have provisions for incorporating Gentiles as Gentiles. Unlike Christianity, Jewish particularism undermines the intrinsic universality of the Abrahamic promise that was intended from the start.

After first stating the problem of the non-universality of Judaism, he therefore presents Christianity as a solution to this problem. That is, the first claim leads to the second claim, that Christianity accomplishes this goal: through the church the Abrahamic covenant "has obtained that universality for all peoples which was of course originally intended." Yet without a supposed problem of Jewish particularity, there would be no need for any solution, let alone a specifically Christian one. Therefore, I would argue that Koch moves from solution (Christian universalism) to problem (Jewish particularism). ${ }^{16}$ This makes sense if one accepts his theological assumptions, but it is not an intrinsic failing of Judaism.

Though I am questioning the grounds upon which Koch makes his critique, I want to consider his argument sympathetically. He is not constructing an anti-Jewish polemic. On the contrary, in general he wants to affirm Judaism and Christianity. His overriding goal is to include Gentile believers in the covenantal community, an idea found as early as Paul (Rom 4; Gal $3^{17}$ ) and central to much subsequent Christian theology. It is more problematic, however, when he does this comparatively, by suggesting that such a goal was unobtainable by an alternative, i.e., Jewish, approach. He wants to demonstrate the unique contribution, indeed necessity of Christianity. Through faith in Christ Gentiles are brought into the Abrahamic covenant. Judaism, by contrast, did not and does not include Gentiles, and is judged deficient by this standard. Again, Jews could accept this description, for Jews do not share this generic goal (let alone its specifically

\footnotetext{
${ }^{13}$ With some exceptions, such as the idolatrous Canaanites; see Joel S. Kaminsky, Yet I Loved Jacob: Reclaiming the Biblical Concept of Election (Nashville: Abingdon, 2007).

${ }^{14}$ One could also question whether Christianity, which traditionally makes salvation available to all universally who affirm a particular faith claim, does not enshrine an alternate form of particularism of its own.

${ }^{15}$ For example, in Jewish texts as far back as the Second Temple period we find discussions of very minimal standards for righteous Gentiles in the so-called Noahide laws; important recent studies on Jewish attitudes toward Gentiles include Alan Brill, Judaism and Other Religions: Models of Understanding (New York: Palgrave MacMillan, 2010); Terence L. Donaldson, Judaism and the Gentiles: Jewish Patterns of Universalism (to 135 CE) (Waco, TX: Baylor University Press, 2008).

${ }^{16}$ I allude to E. P. Sanders' famous description of Paul as moving from "plight" to "solution" in Paul's assessment of Judaism, in E. P. Sanders, Paul and Palestinian Judaism: A Comparison of Patterns of Religion (Minneapolis: Fortress, 1977), 482.

${ }^{17}$ Siker, Disinheriting the Jews: 28-76.
} 
Christian fulfillment). It is therefore accurate to note that Judaism is in his words "particularistic." However, it is only according to his non-Jewish, Christian standard that this is a deficiency. ${ }^{18}$

To demonstrate the correctness of Christianity, then, Koch relies on a comparative approach. If Judaism were not particularistic, Christianity might then simply be superfluous. I appreciate that he faces a serious challenge of both affirming Judaism generally while criticizing those specific aspects of Judaism that Christianity broke with or changed. Christian claims that clash with Judaism require explanation. He does not say both approaches are correct. Aware of the importance of including Gentiles in the covenant, Koch implies that Christianity fulfills God's will.

It is therefore troubling that Koch presents his views in the form of an implicit request to Jews. At the conclusion of his discussion, the statement almost imperceptibly takes on a different format and becomes, we might say, dialogical. He puts this in terms of a question: If Jews recognize this more restrictive description of Jewish views of the Abrahamic covenant, can they next "arrive at the insight" that "the church" is the means for remedying this lack or insufficiency? He subtly but profoundly shifts away from just presenting a report about Catholic reflection on the Abrahamic covenant and, as noted, asks Jews to agree with his interpretations of both Judaism and the essential role of the church.

This is an unreasonable expectation. Jews would have to accept his unflattering portrayal of "particularistic" Judaism. Jews would also have to accept Koch's uniquely Christian assumptions about the Church's role in fulfilling biblical promises to the nations. I do not want to deny that some Jews have praised Christianity for bringing knowledge of the one God to the Gentiles. ${ }^{19}$ However, Koch's claim goes far beyond this. After asking something of Christians (that they recall their rootedness in the Abrahamic covenant), he makes a reciprocal demand of Jews (that they recognize that their own view of the covenant might undermine God's universal purpose "for all peoples").

Koch's favorable statements about Judaism co-exist uneasily with a model of reciprocity that unfortunately is not Jewishly acceptable or genuinely dialogical. It rests on Christian assumptions and appears to have been developed without substantive interaction with Jewish sources or scholars. (Both would have challenged his views.) I am pleased that Koch repeatedly affirms the legitimacy of Judaism and, in this case, the unrevoked covenant between God and Israel. Yet he asks that this undeniably generous Catholic view of Jewish self-understanding likewise be met by a generous Jewish view of Catholic self-understanding. That is, the first and no doubt central part of his argument about God's faithfulness to the Jews is linked directly ("By the same token") to a reciprocal demand on them. To his credit, he does not hint that a Jewish refusal to accept his "insight" imperils their present covenant with God. However, he lays out this inherent contrast in approaches to the salvation of the Gentiles to argue that Christianity, not Judaism, achieves what God intended. Therefore I would suggest that the claim that universalistic Christianity transcends particularistic Judaism should not be followed by the implicit question: Do Jews agree?

\footnotetext{
18 On imprecise and often polemic uses of the terms "universalistic" and "particularistic," see Anders Runesson, "Particularistic Judaism and Universalistic Christianity? Some Critical Remarks on Terminology and Theology," Journal of Greco-Roman Christianity and Judaism 1 (2000): 120-44.

${ }^{19}$ See Brill, Judaism and Other Religions: 63-98; Abraham Joshua Heschel, "No Religion is an Island," in No Religion is an Island: Abraham Joshua Heschel and Interreligious Dialogue, ed. Harold Kasimow and Byron L. Sherwin (Maryknoll, NY: Orbis, 1991): 3-22. See also Philip A. Cunningham, "No Religion is an Island: Catholic and Jewish Theologies of Each Other," Modern Judaism 29 (2009): 27-33.
} 
Quotation 2:

\begin{abstract}
"If Christian theology succeeds in credibly demonstrating that the incarnation of God in Jesus of Nazareth is to be understood as the culmination point and fulfillment of the selfrevealing God of Holy Scripture who turns towards the world, condescends into history and engages in it, Jews for their part could perceive God's self-exposition in bestowing the Torah and in sending the Shechina to the people of Israel as anticipations of what the Christian faith was to develop in the doctrine of the Trinity. In the light of this, Jews and Christians could at least live in mutual respect for one another, or more precisely in respect for the fact that on the one hand Jews, on the basis of their own faith convictions, cannot possibly read the Old Testament other than in the expectation of the unknown one who is to come; and that on the other hand Christians, on the foundation of the common Abrahamic faith, live and testify their faith conviction that the one whose coming is awaited by the Jews will be identical with the Christ whom they believe as the one who has already come" (Part 3).
\end{abstract}

In Part 3, on monotheism and trinitarianism, Koch argues that the appearance of discontinuity between Christianity and the Hebrew Bible (and Jewish interpretations of it) does not trump continuity and thereby leave Christianity unmoored (a la Marcion). Rather, Christian interpretations are fundamentally rooted in these biblical traditions. Claims about Jesus are not a revelation of a "new concept of God." Therefore, Christianity should not be seen as the "betrayal, but as the critical modification of Jewish monotheism" and fulfillment of the biblical promises. Though he says that Jews have long denied "the Christian doctrine of the trinity" and that this divides the two communities, he nonetheless insists that such denial does not sever Jesus, and claims made about him, from his biblical and Jewish roots.

This effort to find a balance between recognizing discontinuity and disagreement while affirming underlying continuity is not itself remarkable. It reflects a traditional Christian conviction that the Hebrew Bible offers a genuine witness to Jesus, despite differences from (and historically disputes over) the ways it is read by Jews. For both religions, the stakes are high, for these disputes center on the nature of God and God's involvement with humanity. Koch is also aware of a long history of polemics between Jews and Christians about Christology and trinitarianism. Christians frequently claimed that the Bible clearly indicates later trinitarian ideas but that Jews were too stubborn or blind to see this. Early defenders of trinitarianism (as far back as the first few centuries CE) used passages from the Hebrew Bible as evidence for multiple persons in the Godhead. ${ }^{20}$

Traditional Christian denunciations of the Jews for failing to understand or accept trinitarian claims have been purged from liturgy and educational resources in most Catholic and (Western) Protestant churches. Most prominently, in The Jewish People and their Sacred Scriptures in the Christian Bible (2001), the Pontifical Biblical Commission, reflecting the Catholic Church's acceptance of historical-critical and literary-critical scholarship, ${ }^{21}$ critiqued "excesses of the allegorical method" in pre-modern eisegesis upon which some trinitarian arguments were based. Such arguments include those that Jews found unpersuasive. This modern shift does not, however, mean that the Commission, or the Church, rejects any biblical witness to the Trinity, or to

\footnotetext{
${ }^{20}$ E.g., Justin, Dialogue with Trypho 56; Tertullian, Against Praxeas 31; see Ellen T. Charry, "The Doctrine of God in Jewish-Christian Dialogue," in Oxford Handbook of the Trinity, ed. Gilles Emery and Matthew Levering (Oxford and New York: Oxford University Press, 2011): 559-72.

${ }^{21}$ This is not a new idea. Endorsement of some of the methods of academic historical-critical study of the Bible is usually dated to the 1943 encyclical Divinio Afflante Spiritu.
} 
Christian theological claims based on the Hebrew Bible generally. Rather, the Commission affirms as legitimate the discovery of a "potentiality of meaning" actually present in the Hebrew Bible. $^{22}$ This refers to an approach to biblical texts that, even "opaquely," uncovers "ternary [i.e., trinitarian] symbolism" eventually manifest with the coming of Jesus. ${ }^{23}$

In contrast to the first (criticized) approach of excessive allegorization, this second approach, the Commission says, is valid in the Church. For those with "Christian eyes," it is a type of "retrospective" recognition of a progressive revelation of Christian truths actually present in Scripture. This means that Jews, who lack this perspective, should not be denounced for rejecting Christian interpretations. ${ }^{24}$ They cannot be expected to see "what has been proclaimed in the text" by Christians. Just as Christians approach biblical texts with Christian assumptions, Jews, the Commission declared, approach biblical texts with Jewish assumptions and offer interpretations that are also "possible." This is a path-breaking statement, reflecting a new tolerance for alternative interpretations without denying the truth of Christian interpretations.

In his discussion of monotheism and trinitarianism, Koch partially neglects this awareness of the ways our assumptions shape our reading of Scripture. In both content and form he steps back from recent demands made to accept Jewish disagreements in this and other Catholic documents and statements. Instead, he presents his request that Jews accede to at least some of the Church's interpretations. Before looking at Koch's view it is helpful to consider another, slightly earlier response to the Jewish "no" by Koch's predecessor at the Pontifical Council for Promoting Christian Unity, Cardinal Walter Kasper. He wrote, "The basis for dialogue must rather be the realization that Jews and Christians differ on these issues [i.e., Christology and trinitarianism] and must respect and appreciate the other in their otherness." ${ }^{25}$ By comparison, Koch, while not denying the disagreement, does not just note it or enjoin, like Kasper, greater "understanding." Rather, he hopes that "[i]f Christian theology succeeds in credibly demonstrating" the truth of trinitarian claims, it might spur a new understanding by Jews of Christian interpretations (parallel to Christians' new understanding of Jewish claims). The linkage between Christian claim and Jewish response is explicit: Christian arguments with credibility or believability-presumably according to some external or objective standard-require a reciprocal Jewish response.

As in the first passage considered above, the format of Koch's argument is striking. He shifts from reporting on Catholic theological reflections about Jews to requesting some type of theological response from Jews. Again assuming the persuasiveness of his argument, he tells Jews what they can "perceive" about God's activity. He tells Jews how they can "read" the Bible messianically. He clearly links his Christian affirmation of the validity of Jewish faith in a future redemption (an affirmation I welcome) with his expectation that Jews affirm continuity between God's "self-exposition" in the Bible and the Trinity (an expectation I of course do not welcome). While Koch's sentences are seldom short, we have a hint of the breadth of the claim he presents for a Jewish response in a lengthy and detailed phrase: “...the incarnation of God in Jesus of Nazareth is to be understood as the culmination point and fulfillment of the self-revealing God of Holy Scripture who turns towards the world, condescends into history and engages in it..." It is vital that Jews too might at least accept that he proves the biblical roots of this idea. The request is firm and clear.

22 Jewish People 64.

23 Jewish People 65.

24 Jewish People 21-22.

${ }^{25}$ Walter Cardinal Kasper, "Foreword," in Christ Jesus and the Jewish People Today: New Explorations of Theological Interrelationships, ed. Philip A. Cunningham, et al. (Grand Rapids, Ml: William B. Eerdmans, 2011): x-xviii, xiii. 
Koch's request seems intended to buttress the legitimacy of his Catholic claim of continuity between the Hebrew Bible and trinitarianism. This claim is strengthened if those with whom Catholics share the Bible (i.e., Jews) at least affirm that later theological developments, above all the Trinity, have their roots in Scripture. He asks for a reciprocal response: Jews "for their part" might respond to Koch's statements by affirming something quite dramatic and unprecedented as well about Christianity. Koch clearly does not believe he is asking Jews to go too far. He believes he is only asking them to affirm what the Bible says-that God's actions in Scripture are "anticipations" of the Trinity-and not what he as a Christian sees with "Christian eyes" (to quote Jewish People).

While Koch's request reflects Christian assumptions about the Bible that he sees as given and incontestable ("credib|[e]"), it is equally unacceptable to Jews. These assumptions are unavoidable, for they reflect our prior religious commitments, and therefore they color our interpretations. There is no objective or neutral perspective from which such claims can be evaluated. ${ }^{26}$ My dissent to his claims reflects my Jewish assumptions that the Tanakh does not foreshadow the Trinity. While I would not criticize Christians' reading with "Christian eyes," he displays a lack of awareness that he is doing so by turning to the Jewish community for a reciprocal and positive response to a Christian interpretation. In light of his insistence on cultivating mutual respect between religions-manifest in his affirmation of the legitimacy of Jewish messianic hopes-Jews cannot but seem ungracious by refusing to agree with him. This is a difficult position for Jews to be put in.

\section{Quotation 3:}

"In this mutual respect Jews and Christians can each fulfill a reciprocal service toward the respective faiths of the other. Where it remains true to its divine calling, Judaism is and remains a thorn in the flesh of Christians, in that it calls Christians to remember the experience of unredeemedness of the world, as Franz Rosenzweig has expressly emphasized: 'This existence of the Jew constantly subjects Christianity to the idea that it is not attaining the goal, the truth, that it ever remains-on the way'. On the other hand, where the Christian church remains true to its divine mission, it is and remains a thorn in the flesh of Judaism, in that it bears witness to the already bestowed reconciliation of God with mankind, without which there can be no well-founded hope for redemption. In this reciprocal service to the faith of the other Judaism and Christianity, synagogue and church remain inseparably bound to one another, as the Reformed theologian Jürgen Moltmann expressed it in an abiding directive for Jewish-Christian conversation: 'For the sake of the Jew Jesus there is no final separation of church and Israel. For the sake of the gospel there is for the present also no fusion into the eschatological future. But there is the pilgrim fellowship of the hopeful'" (Part 4).

In his last section, Koch continues to grapple with, among other things, the Jewish "no" to Christian theological claims. Importantly, he also broadens this to include Christians' dissent from Jewish theological claims. Again, his approach is irenic: out of "mutual respect," Jews and Christians should accept that they can disagree without this provoking conflict or hostility. As an alternative to past polemics, this is a tolerant model of religious interaction. It can even be constructive, he says, as each side can learn from the issues that divide them.

Still, the relationship remains an inherently conflictual and difficult one. Koch vividly describes each side as a "thorn in the flesh" of the other, causing pain but also providing an opportunity for

\footnotetext{
${ }^{26}$ Cunningham and Pollefeyt, "The Triune One," 193.
} 
"reciprocal service" to the other. ${ }^{27}$ In a phrase taken from Rosenzweig, he sees the "existence of the Jew" itself as a challenge to Christian faith. ${ }^{28}$ The theological problem caused by the inexplicable, continuing presence of Judaism has a long history in Christianity. The existence of Jews after Christ raised complex questions for supersessionist Christians, who assumed that they would have converted or disappeared. ${ }^{29} \mathrm{Koch}$, to his credit, departs from the most negative formulation of the challenge of Judaism. Alongside his generic (and I would add unwelcome) reference to the idea of Jewish existence as such as puzzling, he apparently has in mind more specifically Jews' expectation of a messianic age still to come. ${ }^{30}$ The Jewish conviction that the world remains "unredeemed" clashes with the Christian claim that the eschatological fulfillment was inaugurated with the death and resurrection of Jesus.

Koch believes the Jewish conviction (expressed by Rosenzweig) that "the goal...ever remainson the way" can help to moderate a potentially excessive Christian emphasis on redemption as having already occurred. That is, this eschatological tension between "already" and "not-yet" has historically sometimes tilted too much in favor of "already." This distorts Christian expectation about the final redemption at the return of Christ. Koch therefore welcomes the dissenting influence of Jewish thought on this complex topic. Though he does not say this, Jews have a stake in this balance, for Christians have often resented their refusal to recognize the dawning of a new age. $^{31}$

For Jews as well, Koch says, Christianity posed and poses profound challenges. Revealingly, Koch ignores more common and mundane reasons that some Jews paid attention to Christianity, such as its stunning growth and acquisition of worldly power. He instead focuses on strictly theological issues such as redemption and eschatology. Koch argues that, just as Christians cannot but be challenged by Jewish futuristic eschatologies, Jews too are challenged by the Christian conviction that in Jesus humanity experiences the "already bestowed reconciliation of God." The parallelism is explicit: each religious community is provoked by the other and encouraged to respond.

However, the nature of the provocation, though ostensibly reciprocal, is very different, and, I believe, more serious and portentous for Jews. As a counterpart to the Jewish challenge to Christianity noted above, Koch says that, to the Jews, "the Christian Church... bears witness to the already bestowed reconciliation of God with mankind." This explicitly identifies the goal or benefit to humanity, "reconciliation," and implicitly identifies the way it was achieved, through Christ. Koch could surely imagine no one else who "already" initiated this process. ${ }^{32}$ Christ's saving work is universal, salvific, and (at least partly) accomplished. Though Koch earlier suggested

\footnotetext{
${ }^{27}$ The phrase a "thorn in the flesh" presumably is intended to recall Paul's statement that "a thorn was given me in the flesh, a messenger of Satan to torment me, to keep me from being too elated" (2 Cor 12:7). Koch's allusions to the quotation, with its references to Satan and Paul's murky personal struggles, seem out of place in this context.

${ }^{28}$ On Rosenzweig's views of Jewish-Christian dialogue, see Leora Batnitzky, "Dialogue as Judgment, Not Mutual Affirmation: A New Look at Franz Rosenzweig's Dialogical Philosophy," Journal of Religion 79 (1999): 523-44. In light of her persuasive interpretation, it is likely that Rosenzweig would not support the use to which Koch puts him.

${ }^{29}$ For example, Augustine famously sought an answer to the question (as phrased by Paula Fredriksen), "Why does a provident God continue to guard Jewish practice, Jewish presence, Jewish lives?" in Paula Fredriksen, Augustine and the Jews: A Christian Defense of Jews and Judaism (New York: Doubleday, 2008), 371.

${ }^{30}$ This may be a reference to Jewish People 21: "Jewish messianic expectation is not in vain."

31 On the implications of this idea for Jewish-Christian relations, see John Pawlikowski, Christ in the Light of the Jewish-Christian Dialogue (Ramsey, NJ: Paulist, 1982), 74; Rosemary Ruether, Faith and Fratricide: The Theological Roots of Anti-Semitism (Minneapolis: Seabury and Winston, 1974), 244-45.

32 There is an echo here of Rom 8:18-24, esp. vv. 22-24, a passage that uses similar language and also reflects intense eschatological tensions.
} 
that Jews and Christians could, in a sense, agree to disagree, the Christian "thorn" is really about a fundamental soteriological claim.

This is a highly problematic request to Jews, undermining the sense of agreeable disagreement. Koch casts the Christian "thorn" to the Jews as a non-negotiable theological claim about "redemption" in Christ. The Jewish "no" cannot but be a rejection of that which is unquestionably necessary. Unlike the salutary reminder the Jewish "thorn" offers to Christians, here the stakes to the Jews of the Christian "thorn" could not be higher, for without this reconciliation in Christ, Koch says, "there can be no well-founded hope for redemption." Though seemingly offering a parallel request to the one Jews make to Christians, Koch asks Jews to accept not just an eschatology that is "already" but the Christian content of that eschatology (for Koch can have no one but Jesus in mind). Jews inevitably would refuse to accept this, undermining the possibility of reciprocity. For Christians, the Jewish "thorn" is a welcome reminder of that which they should not neglect: that eschatological expectations need to remain in balance, an idea already present in the Christian tradition. It contains no implication that they are wrong. For Jews, however, the Christian "thorn" about the salvific gifts of Jesus for all mankind could never be granted, and yet refusal risks misunderstanding, if not jeopardizing, "redemption."

While members of both faiths can offer "reciprocal service" to each other, Jews face a sharper implicit critique and a stronger demand than Christians. In light of earlier statements that Jews need not believe in Christ in order to be saved, Koch here seems not to make salvation contingent upon acceptance of Christ's role in redeeming all of humanity. However, it does appear that he would welcome Jewish recognition of this without their actual conversion. (The different between these two is not explored.) While there is "truth" in the Jewish challenge to Christians-a truth Christians could grant without much difficulty-there is theological necessity in the Christian challenge to Jews. "Redemption," Koch says authoritatively, is possible in this-Christian-way alone. I do not think it is reciprocity to encourage Christians to become better Christians, and to encourage Jews to accept Christian claims about Christ.

\section{Conclusion}

Reciprocity has an obvious and genuine appeal. The term has positive associations of mutuality. It suggests openness to change and new realizations in response to dialogue with and awareness of the views of the other. Koch certainly means to use it this way, repeatedly linking it with "understanding" and "mutual respect." These are noble goals, though they can also entail potential costs. A problem arises when the costs are too high or the requests are unrealistic. Koch puts Jews in a difficult position of either failing to reciprocate or breaking with central Jewish religious convictions. At the risk of seeming ungracious, I choose the former rather than the latter, for I am unwilling to heed some of his requests. This is disappointing to me, as I would like to respond as favorably as possible, especially in light of his (and the Catholic Church's) remarkable changes in teachings about Jews and Judaism.

Fortunately, I believe the problem is not with reciprocity per se but is limited to the content of Koch's requests. I expected a more accurate assessment of the possibilities for reciprocity than Koch seems to have considered, at least on these most contentious issues. Furthermore, I expected more awareness that Jews and Christians enter the dialogue from different starting points, with different histories, and with different interests. Koch, as a Catholic, speaks of an "irreducible uniqueness" in the Jewish-Christian relationship. He says he cannot but grapple with this tension between connection (e.g., shared Scripture, fidelity to one God) and division (e.g., historical separation, disagreement about Christ). Jews, of course, see things differently. For obvious reasons, Jews traditionally have less interest in grappling theologically with 
Christianity. ${ }^{33}$ Jews' willingness to accept proposals for changes therefore differs from Christians' willingness. Jews too have serious and constructive theological questions about Christianity, though a deep sense of spiritual kinship is more strongly and unavoidably felt by Christians. There is also an imbalance in the depth of the changes that Koch proposes. The requests Koch makes in the passages above, are, I believe, less threatening to core Christian convictions than his requests that Jews accept some of his claims about Christ.

On the other hand, Koch's requests for reciprocity should not only be seen negatively. His boldness in making such requests reflects a sense of comfort and trust. Speaking to an audience that includes Jews (literally and figuratively), he says clearly both what is important to him as a Catholic and what he hopes for from his Jewish "brothers" (and sisters). He speaks forthrightly and without rancor, and expresses himself with care and warmth. That I as a Jew ultimately deem some of his requests unacceptable does not close the door but rather opens it further. I do not think he would disagree. There remain valuable opportunities for future dialogue, as Koch, speaking in a generous and dialogic spirit, says as well: "Jewish-Christian dialogue over the past decades... is a sign of hope for continuing the pilgrim fellowship of reconciliation in faith."

None of my critiques should invalidate this type of discussion. Expressions of hope that one's dialogue partner might be changed by the process or see one's views more sympathetically are appropriate and reasonable. ${ }^{34} \mathrm{I}$ welcome the profound challenge Christian theologians have offered Jews to rethink Jewish views of others, for example. From numerous Christian colleagues and friends I have movingly heard of the desire to be seen by Jews as more than generic Noahides. Their deep sense of connection to the God of Israel, found in Koch's speech as well, raises important questions about the nature of the Jewish covenant. This request, though almost never put in reciprocal terms, nonetheless appropriately reflects a sense that Christian views of Jews and Judaism have changed dramatically, and that Jews might reconsider their own views. Reciprocity is not a demand (and never a threat), but a reflection of a healthy relationship open to change. It is a dialogue worth continuing, as Koch says, and improving.

[Acknowledgments: I want to thank Rosann Catalano, Phil Cunningham, Celia Deutsch, and Christopher Leighton for their valuable feedback and observations about the issues raised by Cardinal Koch's presentation.]

${ }^{33}$ On this difference as it relates to Jewish-Catholic relations, see the recent discussion in Jon D. Levenson, "Can Catholicism Validate Jewish Biblical Interpretation?," Studies in Christian-Jewish Relations 1 (2005): 170-85, 184.

${ }^{34}$ On this issue I dissent from the far more restrictive view of Rabbi Joseph Soloveitchik, who wrote before many of the dramatic changes in Jewish-Christian relations. He opposed interreligious dialogue for, among other reasons, a concern that members of one group would demand changes in the beliefs of another. The temptation was, in his words, to make requests to "trade favors pertaining to fundamental matters of faith," which he thought were especially dangerous for a weak Jewish "community of the few" facing an aggressive "community of the many." See Joseph B. Soloveitchik, "Confrontation," Tradition 6 (1964): 5-29, 25. I want to thank Phil Cunningham for his insights on this topic. 